\title{
Income and Payroll Tax Policy and Labor Supply
}

\author{
JERRY HAUSMAN
}

\section{INTRODUCTION}

Income and payroll taxes account for about 75 percent of federal revenues. The proportion of federal tax revenue raised by these two taxes has gone up markedly in the past decade with the amounts growing faster than the underlying inflation rate. The rise in the income tax collections occurs because of its progressive rate structure and insufficient indexing of tax brackets to account for inflation. The rise in the payroll tax has occurred because of legislative actions to fund social security payments. Both the tax rate of the payroll tax and the maximum earnings limit have increased significantly. In Table 1 we indicate the effects of the income and payroll taxes over the last two decades. Note that the combined percentage of the two taxes has risen from $56 \%$ of government revenues in 1960 to $76 \%$ of government revenues in 1978. This increasing trend is likely to continue in the future.

The current social security law calls for further tax rate increases up through 1990 and beyond, and earnings limit increases up to 1982. While the income and payroll taxes have certainly received adequate attention from economists, it is probably fair to say that most economists accepted their structure as reasonably good. Most economists liked the distributional consequences and believed that the economic cost in terms of economic efficiency was small. This latter conclusion was based on limited empirical work and survey responses that the income tax caused little reduction in labor supply. Some evidence existed which indicated that wives labor supply might be affected by taxation, but the general view was that prime age males' behavior was hardly affected at all.

Jerry Hausman is Professor of Economics, Massachusetts Institute of Technology and Research Associate, National Bureau of Economic Research, Cambridge, Mass. Peter Diamond and Nan Friedlaender have provided helpful comments. Paul Ruud and Ken West were research assistants for this project. The NSF provided research support, 


\section{TABLE 1}

Revenues from Income and Payroll Taxes (billions)

\begin{tabular}{ccccccc}
\hline Year & $\begin{array}{c}\text { Income Tax } \\
\text { Revenues }\end{array}$ & $\begin{array}{c}\text { Payroll Tax } \\
\text { Revenues }\end{array}$ & $\begin{array}{c}\text { Income Tax } \% \\
\text { of Federal } \\
\text { Revenues }\end{array}$ & $\begin{array}{c}\text { Payroll Tax } \% \\
\text { of Federal } \\
\text { Revenues }\end{array}$ & $\begin{array}{c}\text { Tax Rate for } \\
\text { Payroll Tax }\end{array}$ & $\begin{array}{c}\text { Earnings Limit } \\
\text { for Payroll } \\
\text { Tax }\end{array}$ \\
\hline 1960 & $\$ 40.7$ & $\$ 10.6$ & $44 \%$ & $12 \%$ & $3.0 \%$ & $\$ 4800$ \\
1965 & 48.8 & 16.7 & 42 & 15 & 3.625 & 4800 \\
1970 & 90.4 & 38.4 & 47 & 22 & 4.8 & 7800 \\
1975 & 122.4 & 75.7 & 45 & 49 & 6.85 & 14100 \\
1978 & 198.5 & 106.1 & 46 & 30 & 6.05 & 17700 \\
\hline
\end{tabular}


Two mistakes arose from this common interpretation of the income tax. First, even if we grant the hypothesis that the income tax has little overall effect on labor supply, its economic cost might still be substantial. Income taxes have two effects on labor supply. Taxes lower the net wage and reduce labor supply by the compensated substitution effect. But taxes also have an income effect, which causes individuals to work more since they have been made worse off by the tax. The two effects have opposite signs and might well approximately cancel causing only a small net effect on labor supply from income taxation. But, the economic cost of the tax arises from the first effect alone. Thus, the conclusion by many economists that the cost of raising revenue by the income tax is very small is not supported by economic theory if, in fact, the income effect and substitution effect are cancelling each other out. The second problem occurs because virtually all empirical work on labor supply disregarded taxes. The market wage rather than the after-tax wage was used in the labor supply functions. Or alternatively, the tax system was treated as a proportional tax system rather than a progressive tax system.' In a recent paper, Hausman (1979c), I have built on previous research and conducted a study of the effect of tax policy on the labor supply behavior of prime age males, wives of the prime age males, and females who head households. When progressive taxes are entered into a model of labor supply we see a significant effect. The findings indicate that labor supply of the husbands is reduced by about $8 \%$ because of the income and payroll taxation while labor supply of wives is reduced by about $30 \%$. Thus, income taxes do affect labor supply in an important way.

But as $I$ argue in the next section of the paper, economists should focus on the economic cost of income taxation more than on labor supply effects. My findings indicate that the economic cost of raising a dollar of government revenue by the income tax is about $25 \mathbb{C}$ on average in terms of lost welfare. The marginal cost of raising an additional $\$ 1$ government revenue by this means is approximately $40 c$. Thus, the economic cost of the income tax is substantial. At least three possible policy recommendations may follow from these conclusions. First, government expenditure might well be reduced given the cost of raising the necessary revenue. To recommend this policy we would need to study the benefits created

Hall (1973), Hausman and Wise (1976), Burtless and Hausman (1978), and Wales and Woodland (1979) provide the major exceptions for analyzing U.S. tax policy. 
by marginal government expenditure. Here and earlier, questions of income distribution become important. Income distribution considerations are discussed in this paper, but we have very little grasp of what constitutes marginal government expenditure or the benefits which arise from it. A further narrowing of policy options would be required to analyze the expenditure option more deeply. The second policy option is to consider raising a greater proportion of tax revenue from other federal taxes. To recommend this option, we need to know the economic cost of other taxes, such as the corporation tax, in terms of their effect on economic efficiency. We do not have adequate knowtedge of the cost of other taxes to explore this option. Lastly, we could consider altering the income tax structure to raise the same amount of revenue but at lower economic cost. In the paper, we investigate progressive linear income taxes which seem to have favorable effects both with respect to economic cost and labor supply.

Policy options one and three are investigated in this paper. Policy option one is similar to Kemp-Roth type proposals for a decrease in income tax rates. Since our model is partial equilibrium, we look at the effect on tax revenue and the economic cost of taxation holding other factors constant. Our findings indicate that income tax revenues in our sample would decrease by about $6.1 \%$ for a $10 \%$ tax cut and by about $20.3 \%$ for a $30 \%$ tax cut. Labor supply effects and the effects on economic cost are discussed in this paper as well as distributional effects of the tax cut. It is certainly possible that general equilibrium effects would eliminate the estimated reduction in tax revenues, but my results lead me to doubt this possibility, especially in the short run. The third policy option appears much more favorable. The progressive tax considered there is basically as progressive as the current tax system for low incomes but decreases the high marginal rates for high incomes. When raising the same amount of revenue as the current system, the economic cost is decreased by more than one half on average with even a greater decrease at the margin. On the usual efficiency grounds this policy option looks extremely good. But as we discuss in the last section of the paper, objections might well be raised to it because it worsens the income distribution. Questions of the tradeoff between the economic cost (efficiency) and income distribution (equity) are very difficult to treat without making judgments on unobservable preferences. Yet, the investigation of this paper is useful because it indicates the size of the potential tradeoff in terms of a marked reform of our income tax system. 


\section{LABOR SUPPLY, TAXES, AND DEADWEIGHT LOSS}

In this section we first consider a model of individual labor supply of the type which has been used in most empirical analysis. The model is based on individual decision makers rather than some larger unit like a family decision process. In fact, in the empirical estimates which we present we consider only husbands and wives. Thus, our model has the husband's labor supply decision independent of the wife's labor supply decision. The wife makes her decision conditional upon her husband's choice. While this model set-up has been traditionally followed in empirical research in labor supply, I expect research in the near future to be more general in its approach. A more symmetrical treatment of family labor supply decisions would be helpful. A second limitation to the model is that it is both static and partial equilibrium. Intertemporal decisions such as the amount of education that a person receives which may well be affected by taxes are omitted. ${ }^{2}$ Also, the model does not consider demand factors for labor in terms of types of jobs offered with respect to wage and hour packages. Again, a more complete model which incorporates these factors would be desirable.

Once we outline the model of labor supply we will then consider the effect of taxes on labor supply. Labor supply has been the focus of much attention in recent discussions of supply-side economics. As a theoretical proposition, it is well known that the effect of taxes can either be to decrease or increase labor supply. However, the accepted hypothesis among supply-side economists has been that the effect of the current U.S. income tax system has been to decrease the labor supply. The labor supply model helps us to consider this question which is answered in the next section with the empirical estimates. But it needs to be emphasized that the labor supply cannot be the sole focus of discussion of the effect of taxes. Instead, measures of individual welfare need to be considered. Therefore, we introduce the appropriate measures of individual welfare, the equivalent or compensating variation. From the equivalent variation and tax revenue raised we then develop the notion of deadweight loss (often also called excess burden). From an economists viewpoint, deadweight loss is the correct measure of the effect of taxation. While deadweight loss is a somewhat difficult concept, I believe it, rather than labor supply, should be the focus of informed discussion of the effects of taxation. If we accept the

\footnotetext{
${ }^{2}$ Other institutional factors such as pension and social security benefis are not treated due to lack of appropriate data.
} 


\section{FIGURE 1}

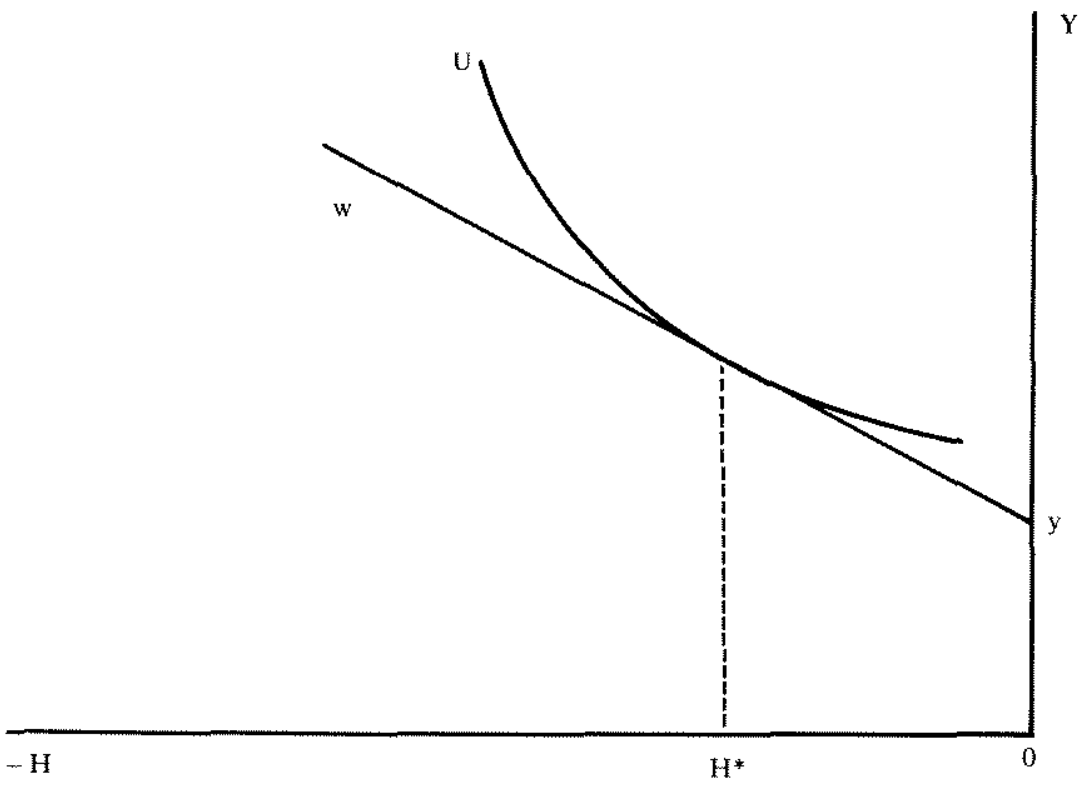

notion that the purpose of the income tax is redistributive as well as a means to raise tax revenue, then deadweight loss defines the correct way to measure the economic cost of the income tax. The error in considering labor supply only is that we can easily design feasible tax policies which raise a given amount of tax revenue while increasing labor supply from the no tax position even though the individual is made worse off by the tax. In this situation it would be incorrect to conclude that the tax is desirable due to its effect on labor supply when the individual's utility has decreased. Furthermore, the redistributive aspect of the income tax would be eliminated by this type of tax so that the change from the current type of system would not be acceptable.

\section{THE MODEL OF INDIVIDUAL LABOR SUPPLY}

The typical model of labor supply used in empirical work has a very simple structure. The individual is assumed to maximize a utility function over hours of work $\mathrm{H}$ and net of tax income $\mathrm{Y}$, $\mathrm{U}(\mathrm{H}, \mathrm{Y}) .^{3}$ Thus, all consumption goods, except leisure, have been

\footnotetext{
${ }^{3}$ Some treatments replace hours of work $\mathrm{H}$ by leisure, $\mathrm{T}-\mathrm{H}$, where $\mathrm{T}$ is total time available. However, since $T$ is an unobservable variable this approach often leads to unnecessary empinical problems.
} 
FIGURE 2

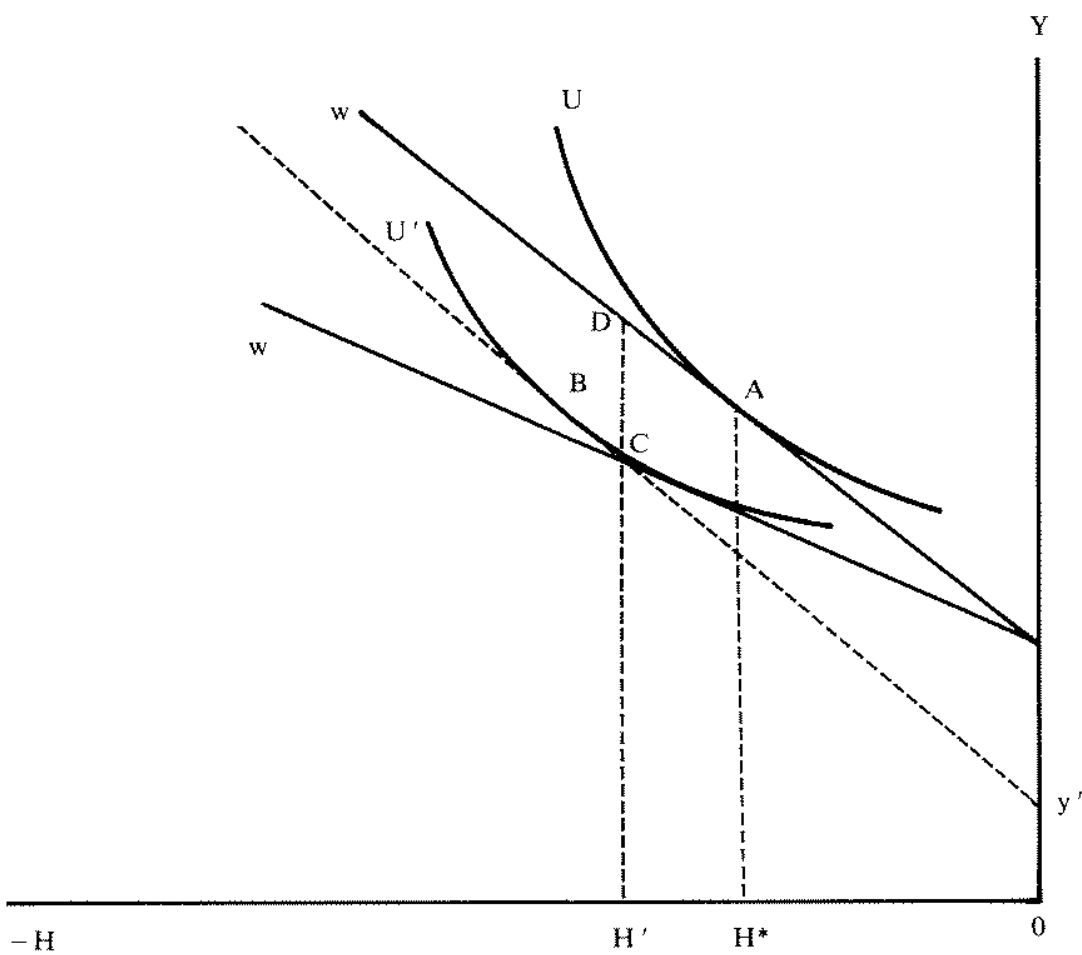

aggregated into a composite good which is represented by the expenditure variable $Y$. Note that since $H$ is a supply variable, rather than a demand variable, the derivative of the utility function has a negative sign with respect to it. The budget constraint then becomes $\mathrm{Y}=\mathrm{y}+\mathrm{wH}$ where $\mathrm{y}$ is nonlabor income and $\mathrm{w}$ is the net after-tax wage rate. ${ }^{4}$ In Figure 1 we present the two-good diagram which corresponds to this model of labor supply. The tangency of the indifference curve which arises from the utility function $\mathrm{U}(\mathrm{H}, \mathrm{Y})$ with the budget line determined by non-labor income and the wage then leads to desired hours of work $\mathrm{H}^{*}$.

In Figure 2 we then consider the effect of a wage change from $w$ to $w^{\prime}$. This change could occur if the government levied a wage tax and exempted nonlabor income, e.g., income from savings. In our subsequent analysis we also allow for taxation of non-labor income, but here look at the simpler case.

${ }^{4}$ In this formulation the wage and income variables are given tn terms of the price of the composite good. 
Note in the diagram that after-tax hours of work $\mathrm{H}^{\prime}$ exceed pretax hours $\mathrm{H}^{*}$. Nothing pathological exists in Figure 2 . We merely have the counteracting influences of the income and substitution effects which have opposite signs under normal assumptions. "The income effect along with the assumption that leisure is a normal good implies that labor supply increases when non-labor income decreases holding the wage constant. In Figure 2, the movement from point $A$ to point $B$ arises from the income effect. The dashed line which is tangent to the lower indifference curve at point $B$ represents the income effect since it is drawn parallel to the original budget line and represents the same wage. The movement along the lower indifference curve from point $B$ to point $C$, then represents the (compensated) substitution effect. It holds utility constant but lowers the wage from $w$ to $w^{\prime}$. Economic theory states that the substitution effect when the net wage falls will decrease labor supply. Thus, even in the most simple case of a wage tax, the income and substitution effects are of opposite sign. Econometric estimates are necessary to measure the total response and magnitudes of the two separate effects. In terms of the Slutsky equation we have the formula

$$
\frac{\partial \mathrm{H}}{\partial w}=\left.\frac{\partial \mathrm{H}}{\partial w}\right|_{\mathbf{U}}+\mathrm{H} \frac{\partial \mathrm{H}}{\partial \mathrm{y}}
$$

where the first term on the right-hand side is the substitution effect and the second term is the income effect. It is important to consider both the income and substitution effects when considering taxation and labor supply. As we will see shortly, it is the substitution effect alone which measures the amount of economic cost of a tax. But the income effect cannot be lost sight of because it normally serves to increase labor supply when a tax is levied and determines how much worse off an individual is made by the imposition of a tax.

\section{THE EFFECT OF PROGRESSIVE TAXATION}

We now consider the effects of two types of progressive income taxes. The first type is a linear income tax with a constant marginal tax rate while the second type of progressive tax has increasing marginal rates and is closer to the current U.S. tax system. The linear income tax has many favorable aspects. Since it has only one

This example should not be confused with the textbook case of a Giffen good which may never have existed in practice. Given many empirical estimates of labot sapply response, we might expect this behavior over a certain range of $w$ and $w$. 
FIGURE 3

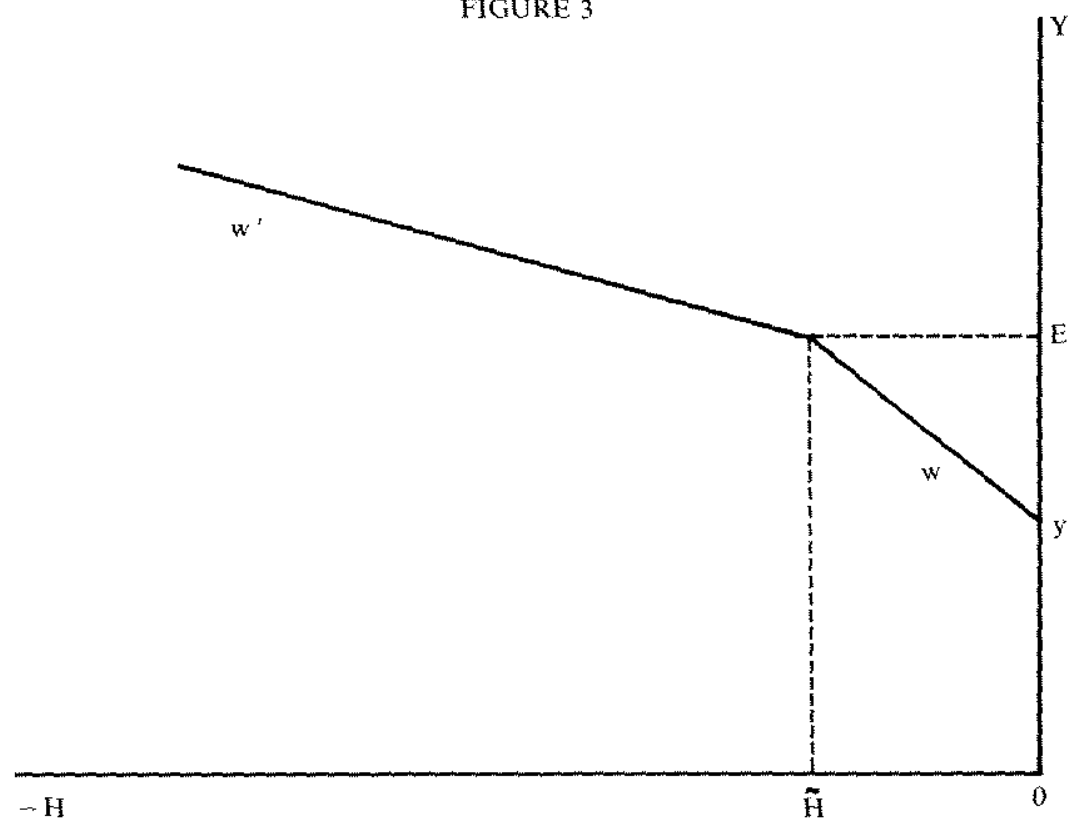

marginal rate it would decrease socially unproductive behavior which individuals currently engage in to reduce their tax liability. The linear tax would lower top marginal tax rates decreasing the incentives for certain types of tax shelters. It can also be made very progressive at the low end through the use of a lump sum grant amount $\mathrm{G}$ or an exemption level E. In Figure 3 we consider the case of a linear tax with a given exemption level. For income up to point $E$ the individual is not taxed so that he recovers his gross market wage $w$. Depending on his wage the exemption level $E$ defines labor supply $\tilde{\mathrm{H}}$ beyond which the individual receives a net wage rate, $w^{\prime}=w(1-t)$ where $t$ is the constant marginal tax rate. Note that while the marginal tax rate is constant beyond $\vec{H}$ the average tax rate is increasing, hence the progressive feature of the tax. And the tax can be made extremely progressive for low $\mathrm{Y}$ by adjusting $\mathrm{E}$. However, a disadvantage occurs at the high end because the progression declines as the average tax rate increases toward the marginal tax rate $t$. 


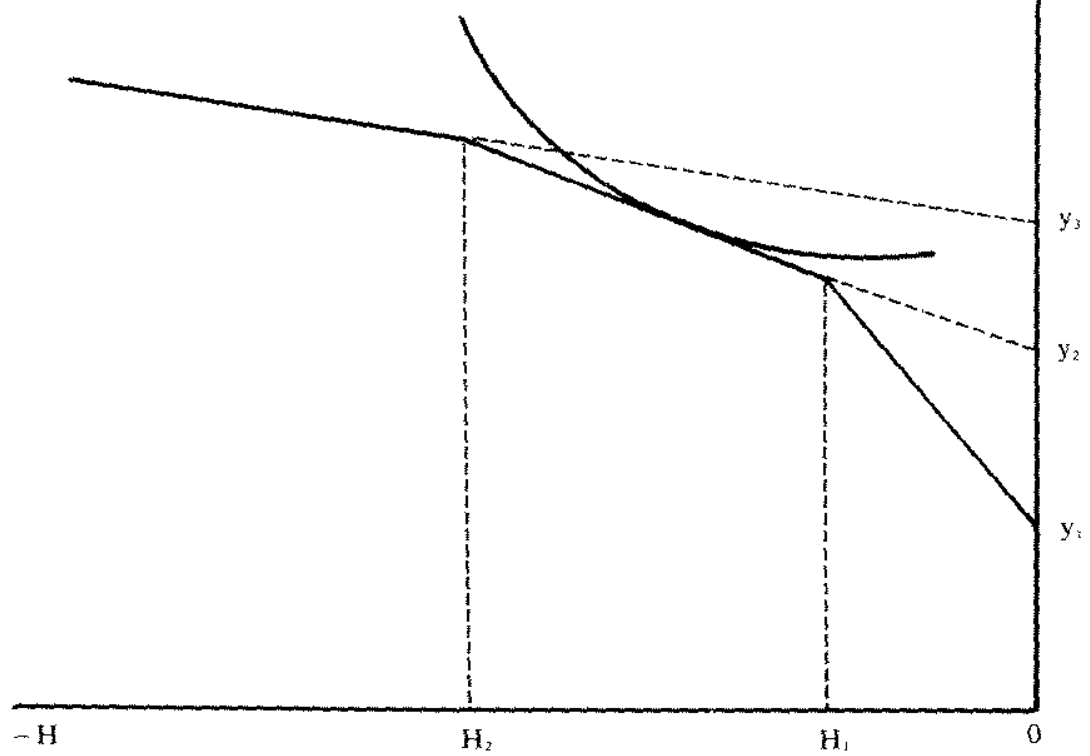

The general progressive tax case is similar to Figure 3 except with more linear segments. 'However, it differs from the previous diagram in that no exemption is present so that each budget segment is determined by a net after tax wage rate of $w_{i}=w\left(1-t_{i}\right)$ and the income brackets over which tholds. After-tax non-labor income is given by $y_{1}$. In Figure 4 we indicate such a budget set with 3 tax segments although the reader should note that the actual U.S. tax code currently has about 15 brackets.

We now address the question of how to use our labor supply model when the budget set is no longer linear as in Figure 1. There we assumed that the individual chose $\mathrm{H}$ to maximize $\mathrm{U}(\mathrm{H}, \mathrm{Y})$ subject to $Y=y+w H$. Here we have a multiplicity of wage rates instead of just $w$. The appropriate technique to use is to define the "virtual" incomes $y_{i}$ which correspond to the wages $w_{i}$ on a particular budget

'Tt is sometimes not recognized that the U.S. tax system is not progressive over its entite range because of the effects of the earned income tax credit, social security contributions, and the standard deduction. These tax provisions make the appropriate budget sets nonconvex instead of convex as in Figures 3 and 4 . We do not treat this additionat complication here but instead refer the reader to Hausman (19796). 
segment. Then along each budget segment the individual maximizes utility subject to $\mathrm{y}_{\mathrm{i}}+\mathrm{w}_{\mathrm{i}} \mathrm{H}_{\mathrm{i}}$. The resulting choice is constrained by the bracket limits which determine $\mathrm{H}_{1}$ and $\mathrm{H}_{2}$ in Figure 4 . That is, the chosen hours of labor supply must be feasible in the sense of being on the budget line in Figure 4 . However, a more straightforward approach is to use a labor supply function (which may be determined from the original utility function) of the form

$$
H_{i}^{*}=g\left(w_{i}, y_{i}, Z, \beta\right)
$$

where $Z$ is a vector of individual socio-economic variables and $\beta$ is a vector of parameters to be estimated. We enter each set of net wages $w$ and virtual income $y$ and at most one tangency with the feasible budget set is found. The tangency then determines labor supply. This result follows because indifference curves for which $\mathrm{g}(\cdot)$ is derived are concave and the budget set is convex. If no feasible tangency is found then we will have bracketed one kink point, e.g., $\mathrm{H}$ and it will be the optimum labor supply. "Thus, in the case of progressive taxes the situation becomes somewhat more complex, but the usual economic theory applies. Also, the notion of virtual income plays a crucial role in the measurement of the welfare costs of taxation which we now turn to.

\section{DEADWEIGHT LOSS FROM TAXATION}

It is incorrect to measure the economic cost of a tax by its total effect on labor supply. As we see in Figure 2 the wage tax served to increase labor supply so on labor supply grounds the tax might be deemed favorable. Yet the individual has been made worse off by the tax since his post-tax indifference curve lies below his pre-tax indifference curve. Furthermore, even if the government returned the amount of tax revenue they raised, which is given by the line segment $\mathrm{CD}$, in the form of the consumption good, the individual has still been made worse off by the tax. Thus, in our simple example the "size of the pie" has increased because the tax has brought forth more labor supply. But still the individual's utility decreases because of the tax. It seems clear that an appropriate welfare measure, rather than labor supply alone, is needed to measure the effect of taxation.

The first component of a welfare measure is the effect of the tax on individual utility. Here the measure long used by economists has

\footnotetext{
${ }^{8}$ This approach is put forward by Hausman (1979b). Other approaches have been used by Ashworth and Ulph (1977) and Wates and Woodland (1979). See also Burtless and Hausman (1978).
} 
been some form of consumers' surplus. Consumers' surplus corresponds to the concept of how much money each individual would need to be given, after imposition of the tax, to be made as well off as he was in the no tax situation. Measurement of consumers' surplus often is done by the size of a trapezoid under the individual's demand curve or here it would be the labor supply curve. But Hausman (1979a) has demonstrated that in the case of labor supply this method is very inaccurate. Instead the theoretically correct notion of either the compensating variation or equivalent variation must be used. ${ }^{9}$ These measures, set forth by $\mathrm{Sir}$ John Hicks, are probably best defined in terms of the expenditure function. The expenditure function determines the minimum amount of money an individual needs to attain a given level of utility at given levels of wages and prices. ${ }^{10}$ Its form is determined by either the direct utility function $\mathrm{U}(\mathrm{H}, \mathrm{Y})$ or the labor supply function, equation (2). In our simple example of the wage tax of Figure 3 the compensating variation equals

$$
\text { C.V. }\left(w, w^{\prime}, U\right)=e\left(w^{\prime}, U\right)-e(w, U)
$$

Equation (3) states that the welfare loss to the individual, measured in dollars of the consumption good, equals the minimum amount of non-labor income needed to keep the individual at his original utility level $\mathrm{U}$ minus his non-labor income in the no tax situation, $y$. Since utility is kept at the pre-tax level $U$, the compensating variation arises solely from the substitution effect in the Slutsky equation (1). The income effect is eliminated because the individual is kept on his initial indifference curve. In the more complicated case of progressive taxes, the only difference is that we use virtual non-labor incomes in equation (3) rather than actual non-labor income. ${ }^{11}$

We need one more ingredient to complete the measure of the welfare loss from taxation. The government has raised tax revenue, and we need to measure the contribution to individual welfare which arises from the government spending the tax revenue. The assumption commonly used is that the government returns the tax

These measures correspond to the area under the compensated demand curve which is determined by the substitution effect in the Slutsky equation (1). For further discussion see Hausman (1979a) or Varian (1978).

"For a more formal treatment see Varian (1978) or Dieweri (1979).

"The alternative measure of the equivalent varation uses post-tax utility $U$ ' as the basis for measuring welfare loss. For labor supply in the two good set-up the equivalent variation typically gives a higher measure of welfare loss than does the compensating variation. 
FIGURE 5

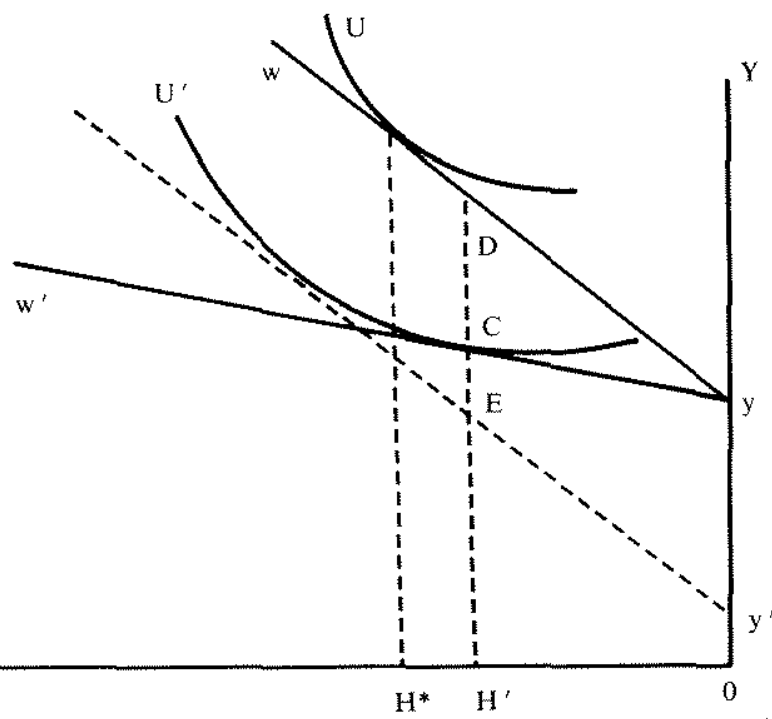

revenue to the individual via an income transfer. Here it would correspond to increasing the individual's non-labor income by the amount of tax revenue raised. Then the total economic cost of the tax is given by the deadweight loss (or excess burden) as

$$
\begin{aligned}
\text { DWL }\left(w, w^{\prime}, U\right) & =C \cdot V \cdot\left(w, w^{\prime}, U\right)-T\left(w, w^{\prime}, U\right) \\
& =e\left(w^{\prime}, U\right)-e(w, U)-T\left(w, w^{\prime}, U\right)
\end{aligned}
$$

Equation (4) states that the deadweight loss of a tax equals the amount the individual needs to be given to be as well off after the tax as he was before the tax minus the tax revenue raised $\mathrm{T}\left(\mathrm{w}, \mathrm{w}^{\prime}, \mathrm{U}\right) \mathrm{.}^{12}$ Deadweight loss is greater than or equal to zero which makes sense given that we expect taxation always to have an economic cost. Thus, even if an individual chooses to work more after the imposition of a tax as in Figure 2, he still has not been made better off by the tax. And the economic cost of the tax to him is given by the deadweight loss formula of equation (4). Of course, if no tax revenue is returned the compensating variation gives the welfare loss to the individual. In Figure 5 the compensating variation and deadweight loss are shown in terms of our simple wage tax example of Figure 2.

\footnotetext{
1. Here we follow Diamond and McFadden (1974) and use taxes raised at the compensated point. Kay (1980) has recently argued in favor of using the uncompensated point. As with $C . V$. and $E . V$. measures the problem is essentially one of which is the better index number basis.
} 
Here the effect of the tax is to reduce labor supply from $\mathrm{H}^{*}$ to $\mathrm{H}^{\prime}$. The compensating variation is measured by the line segment yy'. We then decompose the compensating variation into its two parts. The line segment $C D$ measures tax revenue collected while the line $C E$ measures the deadweight loss of the tax. Since the taxpayer has been made worse off but no one has benefited from the amount of the deadweight loss, it represents the economic cost of raising the tax revenue.

\section{DEADWEIGHT LOSS AND TAX POLICY}

Much of public finance theory is concerned with the question of raising a given amount of tax revenue while minimizing the economic cost as measured by the deadweight loss. ${ }^{13}$ But in considering tax policy redistribution must be accounted for or otherwise we certainly would have no need for a progressive income $\operatorname{tax}$.

Suppose the government wanted to raise tax revenue equal to $R$ dollars. The deadweight loss minimizing tax is a lump sum or poll tax of amount $\tau=R / N$ where $N$ is the number of taxpayers.

Figure 6 portrays such a tax. The deadweight loss is zero because in comparison to Figure 2 or Figure 5 note that only an income effect is present in the movement from point $A$ to point $B$. No

substitution effect is present since the pre-tax wage and post-tax wage are identical. The compensating variation from equation (3) equals $\tau$, the amount of tax revenue raised. Thus, the first term of the Slutsky equation (1) is zero and the change in hours of labor supply comes totally from the income effect. No distortion in relative prices occurs and so no deadweight loss occurs. In equation (4) the compensating variation term is exactly cancelled out by the tax revenue term. Deadweight loss is zero. Furthermore, note that labor supply increases because of the income effect. The result of the lump sum tax is to increase labor supply while not creating any deadweight loss. On economic efficiency grounds it is an ideal tax and also would satisfy supply-side economists goals. ${ }^{14}$ But it is doubtful such a tax would ever be acceptable on political grounds since the redistributive aspect of the current income tax has been lost. In fact, the lump sum tax is extremely regressive since the

${ }^{13}$ For an exposition and references see Chapters $12-14$ of Atkinson and Stiglitz. (1980). Mirrlees (1971) wrote the seminal paper on optimal income tax theory. See also Mirrtees (1979).

:I do not claim to know what the exact goals of supply-side economics are. However, an increase in the national product certanly seems high on the list. 


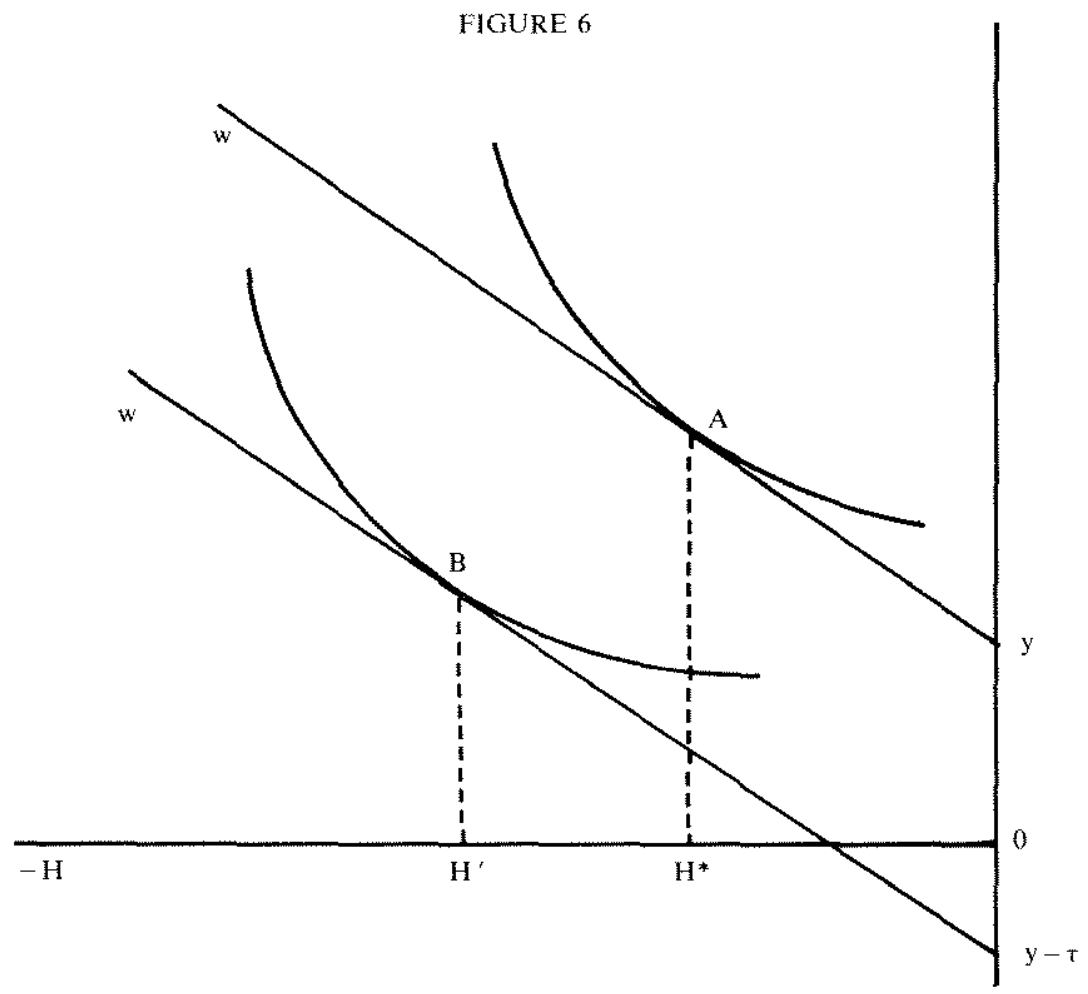

average tax rate decreases with labor income. Even with its favorable supply-side effects, it is doubtful that such a tax would be politically acceptable.

The simple example of a lump sum tax raises a number of important issues. Taxes take away income from people. Taxes, therefore, make people worse off, even if they are nondistortionary. In Figure 6 the individual is on a lower indifference curve after the tax is levied. We measure the economic cost of the tax with the deadweight loss measure of equation (4). But if the tax revenue is not returned to the individual who paid it, he is still worse off. The question of individual losses from the income tax and individual gains to the recipients of tax revenue expenditures involves questions of redistribution. These questions cannot be avoided in discussions of tax policy. Taxes also effect individual behavior again even if they are nondistortionary. Along the lines of Figure 6 we can demonstrate that a lump sum tax which raises revenue $\tau$ always involves greater labor supply than a linear income tax like Figure 3 or a completely progressive tax like Figure 4 so long as 
leisure is a normal good. Therefore, a tradeoff exists between the degree of progressivity that society wants in the income tax and the economic cost measured by the deadweight loss. Thus neither deadweight loss nor labor supply are sufficient measures alone in evaluation of the income tax. Deadweight loss gives the economic cost of the tax, but the "benefit" of the tax which arises due to its redistributive aspect must also be accounted for. Unfortunately, the correct degree of redistribution is difficult to reach agreement on, which makes consideration of income tax policy changes a difficult subject.

\section{AN EMPIRICAL LABOR SUPPLY MODEL AND THE EFFECT OF TAX REFORM Proposals}

In this section we first briefly discuss an empirical labor supply model estimated by Hausman (1979c). The estimates from this model are used to evaluate the effects of income taxation. We then evaluate the effects of the current income tax via both deadweight loss and labor supply effects. Following the analysis of the current tax system, we consider two types of tax reform proposals. The first proposal is referred to as the Kemp-Roth proposal and here we consider reductions in the income tax rates of 10-30\%. Besides deadweight loss and labor supply effects we are also interested in the effect on tax revenue. The change in tax revemue depends on the labor supply response when taxes are changed. If the labor supply response is not uniform across individuals, the change in tax revenue will be sensitive to whether the response is concentrated among high income or low income earners. The other type of tax reform proposal we consider is an equal yield progressive linear income tax like that in Figure 3. That is, we consider income taxes with constant marginal rates which raise the same amount of revenue as the current income tax. The overall tax will still be progressive by letting the exemption level vary across tax reform proposals. The linear tax systems that we consider are similar in progressivity at the low income levels but display much less progressivity at high income levels than the current tax system does. A linear income tax is attractive because it has the potential of sharply decreasing deadweight loss by decreasing high marginal tax rates. But how far it can do so while raising equal tax revenues depends on the labor supply response which we also consider. For each of the tax reform proposals we attempt to account for distributional effects by considering effects among population quintiles. It is important to emphasize that all our results are partial 
equilibrium in nature. Potentially important general equilibrium results are not captured by the econometric model.

\section{AN EMPIRICAL MODEL OF LABOR SUPPLY}

The essential feature that distinguishes econometric models of labor supply with taxes from traditional demand models is the nonconstancy of the net, after-tax wage. As we saw in the previous section, the marginal net wage and the virtual income depend on the specific budget segment that the individual's indifference curve is tangent to. Econometric techniques have been devised which can treat the nonlinearity of the budget set. An econometric model takes the exogenous nonlinear budget set and explains the individual choice of desired hours of work. Our model is based on the linear labor supply specification

$$
\mathrm{h}^{*}{ }_{\mathrm{j}}=\alpha \mathrm{w}_{\mathrm{i}}+\beta \mathrm{y}_{\mathrm{j}}+\mathrm{Z} \gamma
$$

where $w$ is the net after-tax wage, and $y$ is the virtual income on budget segment $\mathrm{i}$. The vector $\mathrm{Z}$ represents socioeconomic characteristics of the individual. The unknown parameters $\alpha, \beta$, and $\gamma$ are estimated using econometric techniques. Now actual hours $h$ may differ from desired hours $\mathrm{h}^{*}$ because of stochastic reasons. Another source of stochastic variation enters the model by allowing for a distribution of preferences in the population via random $\beta$. The specific way in which these enter the model is described in Hausman $(1979 \mathrm{c})$. Also a zero constraint for hours as well as fixed costs to working enter the model. The model is estimated first for a sample of husbands who are between 25-55 years old for the year $1975 .{ }^{15}$ We then estimate the model over a sample of women who are wives of the husbands' sample. The husbands' earnings are treated as non-labor income for the wives. Thus, wives labor supply is conditioned on husbands labor supply. Wives also face initial marginal tax rates given by the last tax bracket which contains their husbands earnings.

The federal income tax is represented in the model by 12 tax brackets. The first bracket is $\$ 1,000$ wide with succeeding brackets falling at intervals of $\$ 4,000$. Since we are interested in the taxes on labor supply, we consider only taxes on earned income. Because we do not have access to actual tax returns, a number of assumptions

\footnotetext{
'It is important to note that neither the model nor the simulations treat the young or old segments of the working population. We would expect a labor supply model to differ markedly for such individuals. Nor do we treat non-married individuals.
} 
are required. We assumed that all married couples filed jointly. In forming the taxable income we took account of personal exemptions and assumed that individuals used the standard deduction up to the (1975) limit of $\$ 16,250$. The standard deduction was used on approximately $2 / 3$ of all tax returns in 1975 . Beyond $\$ 20,000$ we used the average of itemized deductions for joint returns for each tax bracket found in Statistics of Income. We also take account of the earned income credit and social security contributions which were $5.85 \%$ up to a limit of $\$ 14,000$ for 1975 . Lastly, we take account of state income taxes by putting the tax laws of the 41 states who taxed earned income into the budget set calculations. Thus we had a reasonably complete characterization of taxes which individuals faced on their earned income. ${ }^{16}$

We briefly discuss the results from the model for the average individual in the sample. A more complete discussion is contained in Hatsman $(1979 \mathrm{c})$. For husbands we found the uncompensated wage elasticity to be very near zero. This result is similar to the findings of previous research. However, by taking account of the tax system via the virtual incomes we find an income elasticity at the mean hours of work to be approximately -.177 for the mean wage in the sample. Thus, the presence of a non-zero income elasticity implies that husbands' labor supply decisions are affected by the income tax. Also the deadweight loss may be significant because the substitution effect of the Slutsky equation (1) will be non-zero given our estimates. For wives we find the uncompensated wage elasticity to be .906 . The income elasticity for the mean woman who works full time is approximately $-.504 .{ }^{37}$ Thus, both the uncompensated wage elasticity and income elasticity are nonzero which indicates that taxes have an important effect on both labor supply and deadweight loss.

Given the model specification and estimates, we can now apply it to evaluate the effect of income taxation. Suppose we want to evaluate a tax reform proposal. The estimated change in labor supply can be found from equation (6) by entering the new tax plan via the marginal tax rates $w_{i}$ and virtual incomes $y_{j}$. A micro simulation is done on the sample of husbands and wives, and the

\footnotetext{
${ }^{16}$ City income or wage taxes could not be included due to lack of specific job location data. Minor problems may also be created because of the tax treatment by states or earnings of non-residents.

${ }^{17}$ It is important to note that this elasticity is calculated at a mean virtual income of approximately $\$ 8200$. The reason for the high virtual income is that husbands" earnings are included in the non-labor earnings of the wife.
} 
change in labor supply is calculated. The specific manner in which stochastic elements of the model are treated in the simulations is given in Hausman (1980). To do deadweight loss calculations we need the expenditure function for equation (3). Hausman (1979a) derives the expenditure function which corresponds to the labor supply function, equation (5), to be

$$
\mathrm{e}\left(\mathrm{w}_{\mathrm{i}}, \mathrm{U}\right)=\mathrm{e}^{-\beta \mathrm{w}_{\mathrm{i}}} \mathrm{U}+\frac{\alpha}{\beta} \mathrm{w}_{\mathrm{i}}+\frac{\alpha}{\beta^{2}}-\frac{\mathrm{Z} \gamma}{\beta}
$$

We take the marginal wage $w_{1}$ from the budget set and then calculated the deadweight loss from equation (4) using taxes raised at the compensated labor supply point. We then have our welfare measure of the cost of the income taxation. Two possible objections to our welfare measure are that we aggregate across individuals, giving each individual the same weight in the implicit social welfare function. Also different individuals are allowed different coefficients in their expenditure functions. The problems created for analysis of vertical equity considerations for these choices are discussed in Atkinson and Stiglitz (1976). But we attempt to indicate the importance of these considerations by looking at distribution measure across different income categories.

\section{CURRENT TAX POLICY AND KEMP-ROTH REDECTIONS}

We begin our analysis of the current tax policy by considering the effect of the current tax system on the labor supply of husbands. First, we consider the mean individual in the sample. His before tax wage is $\$ 6.18$ per hour and his non-labor income is $\$ 1266$. Without taxes the labor supply model predicts he would work 2367 hours per year, but the effect of the current tax system is to lower his labor supply to 2181 hours per year. Thus, the effect of taxes is to decrease his desired labor supply by $8.2 \%$. To calculate the welfare loss for these husbands we look at the deadweight loss (DWL) based on the compensating variation measure of deadweight loss from equation (3). For the mean individual we calculate the deadweight loss to be $\$ 235$ which is $21.8 \%$ of the total tax revenue collected from him. It is $2.4 \%$ of his net, after-tax income. Thus, we see that taxes on earned income have an important effect on both labor supply and on deadweight loss. These results differ markedly from the received knowledge in the field, e.g., Pechman (1976), which is that taxation has almost no effect on the labor supply of prime age males. Also, the deadweight loss calculation indicates that the 
TABLE 2

Mean Tax Results for Husbands

\begin{tabular}{rrccc}
$\begin{array}{c}\text { Market } \\
\text { Wage }\end{array}$ & DWL & $\begin{array}{c}\text { DWL/Tax } \\
\text { Revenue }\end{array}$ & $\begin{array}{c}\text { DWL/Net } \\
\text { Income }\end{array}$ & $\begin{array}{c}\text { Change in } \\
\text { Labor Supply }\end{array}$ \\
\hline$\$ 3.15$ & $\$ 66$ & $9.4 \%$ & $0.8 \%$ & $-4.5 \%$ \\
4.72 & 204 & 14.4 & 2.0 & -6.5 \\
5.87 & 387 & 19.0 & 3.1 & -8.5 \\
7.06 & 633 & 23.7 & 4.5 & -10.1 \\
10.01 & 1749 & 39.5 & 9.9 & -12.8 \\
\hline
\end{tabular}

income tax is a relatively high cost means of raising tax revenues. ${ }^{18}$ If less expensive means to raise federal tax revenue do not exist, the large amount of redistributive expenditure by the federal government is being done at relatively high economic cost.

Now the mean individual ealculation leaves out two potentially important factors. First, because of the nonlinearity of the tax system, it may provide a poor guide to population averages. It can be shown that deadweight loss is proportional to the square of the marginal tax rate so that deadweight loss will grow quickly as marginal rates rise. Second, distributional considerations are neglected. We have emphasized that an important objective of the income tax system, in addition to raising tax revenue, is to redistribute income. We attempt to investigate distributional considerations by looking at quintiles based on the market wage. The market wage seems a better measure than income to base distributional categories on, because it is closer to the notion of the opportunity set of the individual. In an optimal tax calculation, the tax is based on the opportunities facing the individual instead of post-tax behavior.

In Table 2 we look at the effect of the current tax system for five categories defined by the market wage. Overall, we find that the tax system decreases labor supply by $8.5 \%$ and the mean deadweight loss as a proportion of tax revenue raised is $28.7 \%$. Thus, the results are not too different from the results for the mean individual. However we note important differences among the five categories.

\footnotetext{
${ }^{18}$ Of course, the economic cost of raising revenue from other federal taxes would need to be investigated before an informal choice could be made. Federal taxes on labor income curtently taise about $75 \%$ of federal sevenues.
} 
First, we see that deadweight loss rises rapidly with the market wage as we expected. In terms of the welfare cost of the tax we see that the ratio of deadweight loss to tax revenue raised starts at $9.4 \%$ and rises to $39.5 \%$ by the time we reach the highest wage category. Again we see that the cost of raising revenue via the income and payroll taxes is not negligible. In terms of a distributional measure we see that the ratio of deadweight loss to net income also rises rapidly. In fact, this measure indicates that individuals in the highest wage category bear a cost about 10 times the lowest category while individuals in the second highest category bear a cost 5 times as high. Without specific social welfare measure, we cannot decide whether the current tax system has too much, too little, or about the right amount of progressiveness. But the measures of Table 2 seem an important step in thinking about the problem. Lastly, note that the change in labor supply from the no tax situation again rise with the wage category. The high marginal tax brackets have a significantly greater effect on labor supply than do the low tax brackets.

We now do a similar set of calculations for our sample of wives. While we found both significant deadweight loss and an important effect on labor supply for husbands compared to the no tax situation, the situation is more complicated for wives. First, about half of all wives do not work. In the absence of an income tax, the net wage would rise causing some of them to decide to work and others to increase their labor supply. But, at the same time their husbands' after-tax earnings would also rise which has the opposite effect on labor force participation. Thus, both effects must be accounted for in considering the effects of the income tax.

TABLE 3

Mean Tax Results for Wives

\begin{tabular}{ccccc}
$\begin{array}{c}\text { Market } \\
\text { Wage }\end{array}$ & DWL & $\begin{array}{c}\text { DWL/Tax } \\
\text { Revenue }\end{array}$ & $\begin{array}{c}\text { DWL/Net } \\
\text { Income }\end{array}$ & $\begin{array}{c}\text { Change in } \\
\text { Labor Supply }\end{array}$ \\
\hline$\$ 2.11$ & $\$ 23$ & $4.6 \%$ & $.3 \%$ & $+31.2 \%$ \\
2.50 & 119 & 15.3 & 1.3 & -14.2 \\
3.03 & 142 & 15.9 & 1.5 & -20.3 \\
3.63 & 184 & 16.5 & 1.7 & -23.8 \\
5.79 & 1283 & 35.7 & 8.6 & -22.9 \\
\hline
\end{tabular}


Overall for wives, we find the ratio of deadweight loss to tax revenue to be $18.4 \%$. But it should be remembered that this ratio understates the effect on labor force participants alone. For labor supply, we find that taxes serve to increase labor supply in the lowest wage category, but decrease labor supply as the wage rises. Overall, they decrease labor supply by $18.2 \%$. Thus, again for wives we see that the current income tax system has both an important labor supply effect and imposes a significant cost in welfare terms for raising tax revenue.

We now turn to a consideration of Kemp-Roth type tax proposals. We will consider two levels of tax cuts, $10 \%$ and $30 \%$. The question which has been focussed on most is what effect these tax cuts would have on tax revenues. Our results are partial equilibrium so that general equilibrium effects are not accounted for. The main effect here arises from the change in labor supply. But increased labor also moves some individuals into higher tax brackets. Both effects need to be accounted for, In Table 4 we present the two Kemp-Roth simulation results. For the 10\% tax deduction mean hours of labor supply for husbands rise 22.5 hours or $1.1 \%$. Tax revenues fall by $7.4 \%$. Even given the fact that our model is partial equilibrium, rudimentary calculations demonstrate that general equilibrium effects are very unlikely to be large enough to cause tax revenues from decreasing significantly in the short run as our results show. In terms of the welfare cost of the tax we see that the DWL falls significantly. The ratio of mean deadweight loss to tax revenue falls from $22.1 \%$ under the current system to $19.0 \%$ under the $10 \%$ tax cut plan, ${ }^{19}$ For the $30 \%$ tax cut labor supply increases by $2.7 \%$ while tax revenue falls by $22.6 \%$. Again we see that deadweight loss decreases significantly with the ratio of deadweight loss to tax revenues raised decreasing to $15.4 \%$. Thus Kemp-Roth type tax cuts have large effects both in terms of decreasing deadweight loss and in decreasing government revenue. Without knowledge of marginal government expenditure, it is difficult to evaluate the tradeoff. But we cannot recommend KempRoth on welfare grounds alone given the substantial fall in government revenue.

\footnotetext{
${ }^{19} \mathrm{~A}$ problem arises here because we are doing welfare calculations with different indifference curves because of the tax changes. But we are using a common basis of comparison, the no tax situation.
} 


\section{TABLE 4}

Kemp-Roth Tax Cut Proposals for Husbands

\begin{tabular}{ccccccc}
\hline & & \multicolumn{2}{c}{$10 \%$ Tax Cut } & & \multicolumn{2}{c}{$30 \%$ Tax Cut } \\
$\begin{array}{c}\text { Market } \\
\text { Wage }\end{array}$ & $\begin{array}{c}\text { DWL/Tax } \\
\text { Revenue }\end{array}$ & $\begin{array}{c}\text { DWL/Net } \\
\text { Income }\end{array}$ & $\begin{array}{c}\text { Change in } \\
\text { Labor Supply }\end{array}$ & $\begin{array}{c}\text { DWL/Tax } \\
\text { Revenue }\end{array}$ & $\begin{array}{c}\text { DWL/Net } \\
\text { Income }\end{array}$ & $\begin{array}{c}\text { Change in } \\
\text { Labor Supply }\end{array}$ \\
\hline$\$ 3.15$ & $8.5 \%$ & $.7 \%$ & $+.4 \%$ & $6.8 \%$ & $.4 \%$ & $+1.3 \%$ \\
4.72 & 13.3 & 1.7 & +.5 & 10.9 & 1.1 & +1.6 \\
5.87 & 17.4 & 2.6 & +.9 & 14.5 & 1.8 & +2.7 \\
7.06 & 21.8 & 3.8 & +1.1 & 17.9 & 2.5 & +3.1 \\
10.01 & 36.1 & 8.2 & +1.4 & 29.5 & 5.3 & +4.6 \\
\hline
\end{tabular}


For wives we do not present detailed quintile results because the overall pattern is similar to husbands. The mean results are given in Table 5.

TABLE 5

Overall Kemp-Roth Tax Cut for Wives

\begin{tabular}{lccc} 
Tax Cut & $\begin{array}{c}\text { Change in } \\
\text { Tax Revenue }\end{array}$ & Change in DWL & $\begin{array}{c}\text { Change in } \\
\text { Supply (Hours) }\end{array}$ \\
\hline $10 \%$ & $-3.8 \%$ & $-10.6 \%$ & +50.2 \\
30 & -16.2 & -17.4 & +117.0 \\
\hline
\end{tabular}

Overall, we see that the labor supply response to a tax cut is greater for wives than for husbands. We expect this since the wage elasticity is about twice the income elasticity so we should have a net increase in labor supply. Furthermore the difference in the elasticities is about four times that of husbands, and we do observe a significantly larger response. For the $10 \%$ tax cut case labor supply increases by $4.1 \%$ and tax revenues fall by $3.8 \%$. For the $30 \%$ tax cut case labor supply increases by $9.4 \%$ and tax revenues fall by $16.2 \%$.

Our overall evaluation of the Kemp-Roth tax proposals is that while tax revenues will decrease by significantly less than the tax cut, overall government revenue from the income and payroll tax will decline. An argument might be made that general equilibrium results may be large enough to reverse this conclusion, but I doubt that it is a valid argument, especially in the short run. Thus, unless a strong argument can be made for reducing government expenditures with little welfare loss from the recipients, the KempRoth tax cut proposals cannot be supported on the basis of our results. They certainly do not have the "free lunch" properties claimed by some of their supporters.

\section{A LINEAR INCOME TAX}

We now consider an equal yield change from the current tax system to investigate whether the welfare cost in terms of deadweight loss can be significantly decreased. The type of tax system which we consider are linear income taxes with initial 
exemptions like the tax system drawn in Figure 3. Thus, we specify an initial exemption $\mathrm{E}$ and then search our marginal tax rates until we find the minimum tax rate which raises the same amount of tax revenue as the current tax system. We might expect such a linear income tax to do well in two respects. ${ }^{20}$

First, in Table 2 we saw that deadweight loss increases rapidly as marginal tax rates increase. Since the linear income tax will not have such high marginal rates, deadweight loss should be decreased. Second, we would expect a significant labor supply response given a decrease in the marginal tax rates. Thus, the tax rate should not have to be too high to raise equal revenues to the current tax system. Yet a potential problem still exists. Even if total deadweight loss decrease, some individuals may still be made worse off by a change from the current tax system to a linear income tax. Although overall deadweight loss will decrease, we have the problem of potential versus actual compensation which was the basis of the Kaldor-Hicks-Scitovsky-Samuelson debate of the 1940 s. However, we will see that the linear income tax does so well that the problem may be overcome in some cases.

In Table 6 we consider the equal yield linear income tax for husbands. Note first that the tax rate begins at $14.6 \%$ with an exemption level of zero and rises to $20.7 \%$ with an exemption of $\$ 4000$. Each tax measure gives a substantial welfare gain. Since tax revenues remain the same the change in deadweight loss gives the welfare improvement. Note that even with the highest exemption level of $\$ 4000$ the deadweight loss falls by $49 \%$ from the current system. The labor supply also increases substantially from the current system. My conjecture is that except for a lump sum tax, we have done about as well as possible because labor supply is now only approximately $1.5 \%$ below the no tax case. Lastly, we look at the question of distribution. By considering the average tax rate for various exemption levels, we see that either the $\$ 2000$ or $\$ 4000$ exemption is superior to the current tax system since the average (as well as the marginal) tax rate is lower at every tax bracket. The results are sensitive to various deductions and credits an individual taxpayer declares but yield the conclusion that approximately all taxpayers are made better off by this type of linear income tax system. ${ }^{21}$

${ }^{20}$ Mirtees (1971), when he considered the optimat monlinear income tax found that the optimal tax was nearly linear for the particular labor supply function he considered.

${ }^{2}$ The earned income tax credit is taken into account in these calculations, 
TABLE 6

Equal Yield Linear Income Tax

With Initial Exemption for Husbands

\begin{tabular}{|c|c|c|c|c|c|c|c|c|}
\hline \multirow{2}{*}{$\begin{array}{l}\text { Exemption } \\
\text { Level }\end{array}$} & \multirow[b]{2}{*}{ Tax Rate } & \multirow{2}{*}{$\begin{array}{c}\text { Change in } \\
\text { Deadweight Loss }\end{array}$} & \multirow{2}{*}{$\begin{array}{c}\text { Deadweight Loss/ } \\
\text { Tax Revenue }\end{array}$} & \multirow[b]{2}{*}{ Change in Hours } & \multicolumn{4}{|c|}{ Average Tax Rate at: } \\
\hline & & & & & 4000 & 8000 & 16000 & 24000 \\
\hline 0 & $14.6 \%$ & -825.75 & .071 & +170.0 & .146 & .146 & .146 & .146 \\
\hline$\$ 1000$ & 15.4 & -798.82 & .083 & +169.3 & .116 & .135 & .144 & .148 \\
\hline 2000 & 16.9 & -765.31 & .098 & +167.6 & .085 & .127 & .148 & .155 \\
\hline 4000 & 20.7 & -659.18 & .145 & +163.0 & 0 & .104 & .155 & .172 \\
\hline $\begin{array}{l}\text { Current } \\
\text { Tax Code }\end{array}$ & IRS Code & - & .287 & - & .119 & .147 & .173 & .188 \\
\hline
\end{tabular}


TABLE 7

Linear Income Tax for Wives

\begin{tabular}{ccccc}
\hline $\begin{array}{c}\text { Exemption } \\
\text { Level }\end{array}$ & Tax Rate & $\begin{array}{c}\text { Change } \\
\text { In Taxes }\end{array}$ & $\begin{array}{c}\text { Deadweight } \\
\text { Loss } / \\
\text { Tax Revenue }\end{array}$ & $\begin{array}{c}\text { Change } \\
\text { In Hours }\end{array}$ \\
\hline 0 & $14.6 \%$ & $-5.1 \%$ & .104 & +372.6 \\
$\$ 1000$ & 15.4 & -.3 & .110 & +345.1 \\
2000 & 16.9 & +4.6 & .114 & +302.2 \\
4000 & 20.7 & +11.2 & .143 & +232.8 \\
\hline
\end{tabular}

We briefly consider what effect this type of tax system would have on wives. We assume here that each family gets only one exemption and faces the same marginal tax rates as her husband. We use the tax rates from Table 6 so that tax revenue for wives is not held constant. The results are presented in Table 7. As we expect, labor supply increases for women with the linear income tax because the marginal tax rate has decreased. Because of the increase in labor supply, the revenue changes are not that large. Tax revenues fall by $5.1 \%$ for a $14.6 \%$ tax rate but rise by $11.2 \%$ for the case of a $20.7 \%$ tax rate. The ratio of deadweight loss to tax revenues falls markedly from the current tax system. Thus, for wives as well as husbands, the linear income tax has favorable implications from an economic cost viewpoint.

Our example bears out to some extent the lessons from the optimal tax literature. The crucial parameters there are the weighted (compensated) substitution response and the net revenue raised from each individual. We use the same weights for each individual in our deadweight loss calculations. Our results indicate the importance of the net revenue consideration. Because of the labor supply response, Tables 6 and 7 demonstrate that lower income groups can gain from lowering the top marginal income tax rates. Can anyone then object to the case for a linear income tax? The answer is unfortunately yes, if it is relative rather than absolute income or utility that matters for society's choices on distribution matters. ${ }^{22}$ Economists used to the Pareto principle typically think of each individual's or family's welfare apart from the rest of the

\footnotetext{
${ }^{22}$ Such cases are analyzed by Fair (1971) and Boskin and Sheshinski (1978).
} 
population. Since the linear income tax has the possibility of making everyone better off, most economists would favor it on these grounds. But by sharply decreasing the top marginal rates from say $50 \%$ to $20.7 \%$, the highest paid individuals have a greater increase in welfare than do the lowest paid. Therefore, on a relative basis or by some income distribution measures, the linear income tax might not be an improvement from the current tax system. These arguments would need to be considered in tax reform discussions. I favor such a change in our tax system because 1 do not give great weight to the relative welfare argument. Favorable economic effects could occur with less progression in the tax system at higher income levels. This type of proposal emphasizes the economic efficiency aspects of the tax system. Thus, it seems that a more linear type of tax system is to be favored over the current system. The Kemp-Roth tax cuts do not do nearly as well by comparison. 


\section{REFERENCES}

Ashworth, J. and D. T. Ulph. "On the Structure of Family Labor Supply Decisions." mimeo, 1977.

Atkinson, A. B. and J. E. Stiglitz. "The Design of Tax Structure: Direct Versus Indirect Taxation." Journal of Public Economics, $6(1976)$. Hill, 1980.

Auerbach, A. J. and H. S. Rosen. "Will the Real Excess Burden Please Stand Up? (Or Seven Measures in Search of a Concept)." mimeo, 1980.

Boskin, J. J. and E. Sheskinski. "Optimal Income Distribution When Individual Welfare Depends on Relative Income." Quarterly Journal of Economics, 92 (1978).

Burtless, G. and J. A. Hausman. "The Effect of Taxation on Labor Stpply." Joumal of Political Economy, 86 (1978).

Diamond, P, and D. McFadden. "Some Uses of the Expenditure Function in Public Finance." Journal of Public Economics, 3 (1974).

Diewert, W. E. "Duality Approaches to Microeconomic Theory." mimeo, 1979.

Fair, R. C. "The Optimal Distribution of Income." Quarterly Joumal of Economics, 85 (1971).

Hall, R. E. "Wages, Income and Hours of Work in the U. S. Labor Force." in G. G. Cain and H. W. Watts, eds., Income Maintenance and Supply, Chicago: Academic, 1973.

Hausman, J. A. "Exact Consumers' Surplus and Deadweight Loss." American Economic Review, forthcoming, 1979a. Letters, 3 (1979b).

"The Effect of Taxes on Labor Supply." In H. Aaron and J. Pechman, eds., How Taxes Affect Economic Behavior, Washington: Brookings Institution, 1981.

"Stochastic Problems in the Simulation of Labor Supply." prepared for NBER conference, Octobet 1980. 
Hausman, J. A. and D. Wise. "Evaluating the Results from Truncated Samples." Annals of Economic and Social Measurement, 5 (1976).

Kay, J. A. "The Deadweight Loss from a Tax System." Journal of Public Economics, 10 (1980).

Mirrlees, J. A. "An Exploration in the Theory of Optimum Income Taxation." Review of Economic Studies, 38. ."The Theory of Optimal Taxation." mimeo, 1979.

Pechman, J. Federal Tax Policy (3rd ed.) Washington: Brookings Institution, 1976.

Varian, H. Microeconomic Analysis. New York: Norton, 1978. 